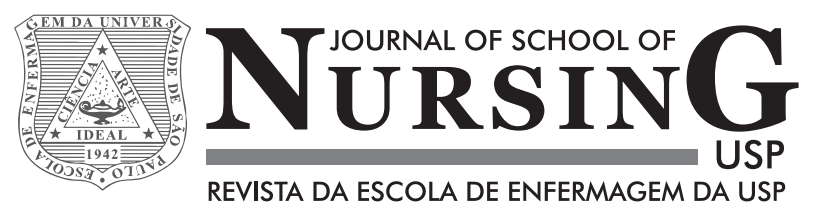

\title{
Family caregivers: what do they need? An integrative review
}

\author{
Cuidadores familiares: o que eles necessitam? Uma revisão integrativa \\ Cuidadores familiares: ¿qué necesitan? Una revisión integrativa
}

Carla Sílvia Fernandes ${ }^{1}$, Margareth Angelo²

How to cite this article:

Fernandes CS, Angelo M. Family caregivers: what do they need? An integrative review. Rev Esc Enferm USP. 2016;50(4):672-678. DOI: http://dx.doi.org/10.1590/ S0080-623420160000500019

\footnotetext{
${ }^{1}$ Escola Superior de Enfermagem Santa Maria, Porto, Portugal.

${ }^{2}$ Universidade de São Paulo, Escola de Enfermagem, Departamento de Enfermagem Materno-Infantil e Psiquiátrica, São Paulo, SP, Brazil.
}

\begin{abstract}
Objective: Aimed to identify the main needs expressed by family caregivers in caring for a dependent person. Method: An integrative review of the literature in the period between 2010 and 2015 using specific search engine tools in the EBSCO and SCOPUS databases. Results: 11 articles were selected, and the analysis of the scientific evidence obtained allowed for organizing the results into five thematic areas: transition into care, being responsible for everything, the importance of support, access to formal support, communication and information processes. Conclusion: The results showed that caregivers have many needs in different areas, which should be addressed in nursing interventions.
\end{abstract}

\section{DESCRIPTORS}

Caregivers; Family; Home Nursing; Disabled Persons; Nursing Care; Review. 


\section{INTRODUCTION}

Many families experience a situation of disease during the course of their life cycle and are faced with the transition into a new role: Being the Caregiver. Family caregiving emerges as a resource for dehospitalization, where people who are unprepared to perform care are expected to perform care which would be the responsibility of paid professionals in a hospital or community. On returning home, the family is weakened and the family caregiver provides care, often intuitively, and there may be flaws in care, either resulting from the absence or lack in guidance received at the hospital that do not meet the real needs of the caregiver or the little time they have to learn the guidelines ${ }^{(1)}$.

Understanding the family care experience is to enter into a complex universe and at the same time it is unique ${ }^{(2)}$. The experience of caring for a dependent patient at home has become increasingly common in the daily lives of families and emerges as a resource for health institutions. This new role is experienced through a multitude of needs and feelings, often contradictory and antagonistic, due to the associated tension, competence and conflict. The onset of the disease within a family that leads the ill member to dependence also leads to the need to change their daily life activities, and this role is usually taken on by the caregiver who is usually a woman, single, a housewife or unemployed and lives together with the dependent person. The expectation that women should continue to support this disproportionate burden remains a silent assumption in most of the policy decision-making(3). This role presents itself as an extension of the expected roles of the family, which combined with the sustainability alleged by health institutions pressures the family to play this role, without considering the requirements and needs associated with $\mathrm{it}^{(4)}$. Numerous studies have been developed in this sphere of caregivers for dependent patients afflicted with different pathologies.

By resorting to an integrative literature review, we aim to identify the needs which are more evidenced by family caregivers of dependent patients emerging from the scientific production of the past five years, and thusly contribute to improving nursing care. In this context, the integrative review allows quick access to relevant research findings that support nurses' decision making ${ }^{(5)}$.

\section{METHOD}

We resorted to an integrative review in order to group the existing knowledge about the needs of family caregivers of a dependent patient. This method is the most comprehensive approach regarding reviews, allowing for including different types of studies for a wider understanding of the analyzed phenomenon, and thereby playing an important role in evidence-based nursing practice ${ }^{(6)}$. The integrative review is an important tool in the process of communicating research results, since it provides a summary of produced knowledge ${ }^{(5)}$.

Considering the knowledge that we intended to summarize, the review had the following question as its starting point: What are the needs of family caregivers of dependent patients?

After identifying the theme and selecting the research question, the criteria for inclusion and exclusion of studies were established. Inclusion criteria were studies with family caregivers of dependent patients in the household, the caregiver being older than 18 years, and in which the study objective was to identify the needs of caregivers. Exclusion criteria were review articles, studies whose theme was centered on family caregivers who were less than 18 years of age and studies with institutionalized care. Bibliographic research was carried out between September and December 2015. Articles published between January 2010 and December 2015 were selected using English, Spanish and Portuguese as languages. To this end, the research was conducted in available health databases, namely EBSCO and SCOPUS, through the following descriptors and Boolean: (Family caregiver OR Parents caregiver) AND (Patient OR Dependent care OR aged) AND (Heath services needs OR Information needs OR Needs) (Figure 1). The research was conducted using the abstract/title of the article and only articles with full texts available were included.

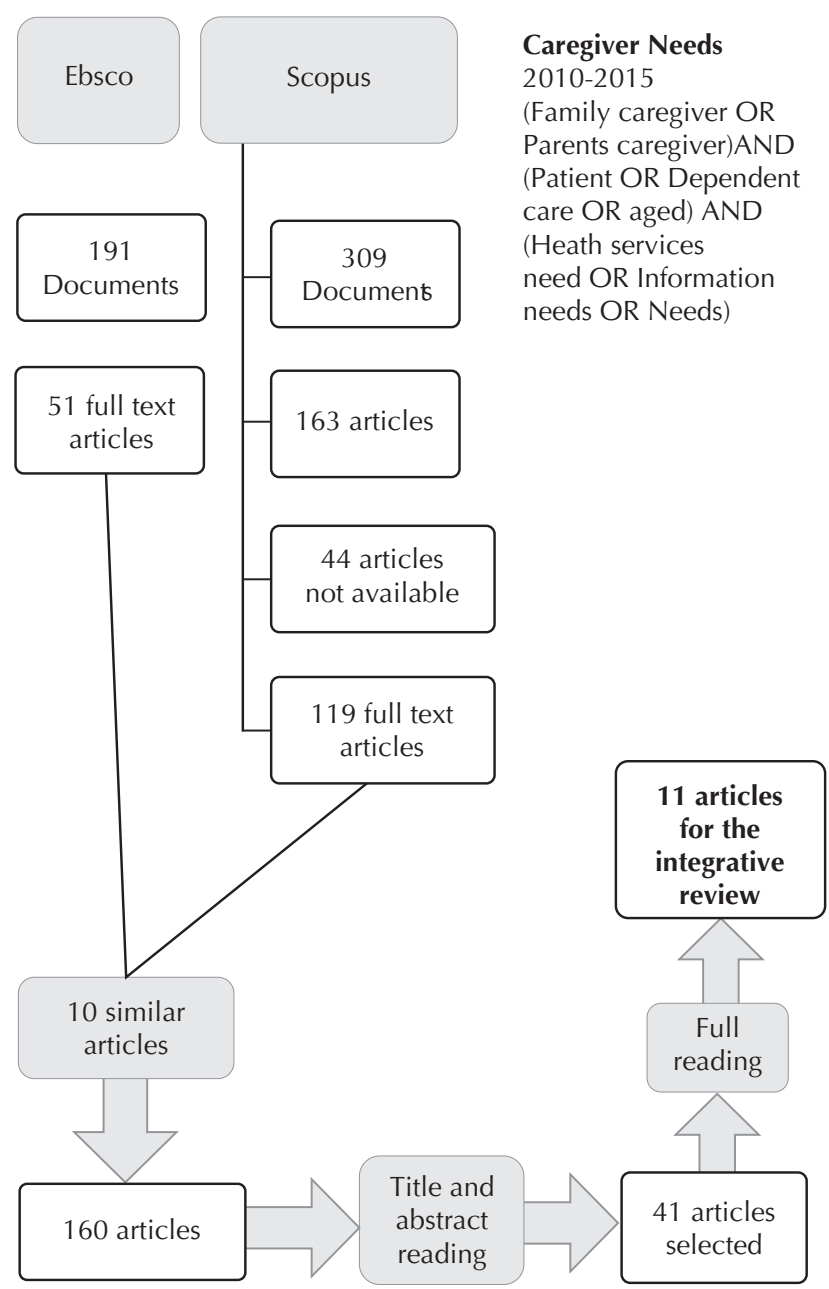

Figure 1 - Research Protocol Construction - Portugal, 2016.

After a full reading of the 41 studies, the final sample consisted of 11 articles that met the inclusion criteria. After establishing the sample, the information to be extracted from the studies was defined and categorized ${ }^{(5)}$. The 11 articles were analyzed in depth and grouped by similarity. 


\section{RESULTS}

This review consists of 11 articles published between 2010 and 2015. Six studies from the selected sample were qualitative and five were quantitative. They were distributed as illustrated in Figure 2, in the following countries: Canada, USA, Brazil, Colombia, England, Italy and Thailand.

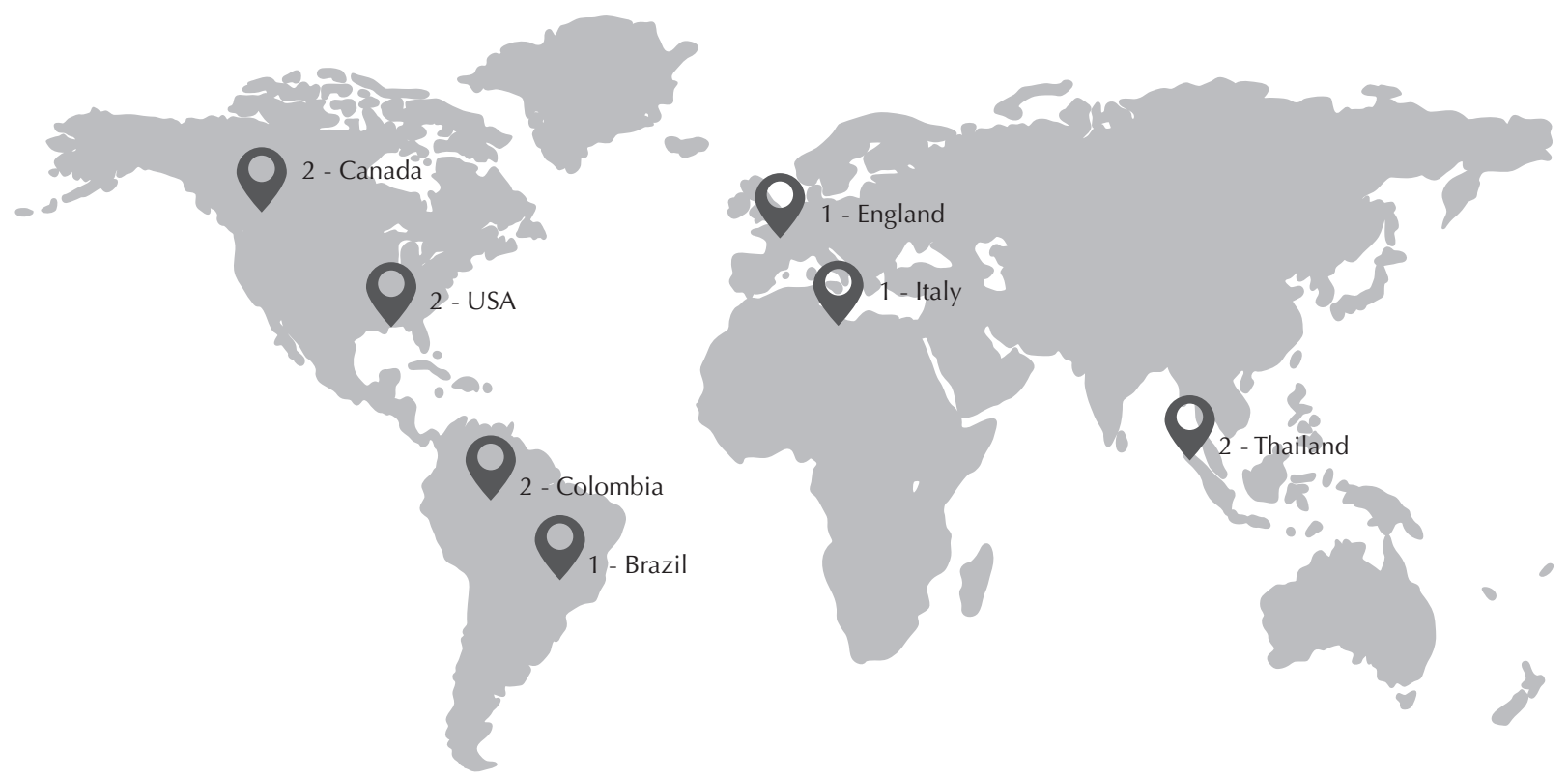

Figure 2 - Geographic scope of the research between 2010 and 2015 - Portugal, 2016.

In the research conducted we obtained many studies that, despite referring to the needs of family caregivers for dependent people, they mostly focused on describing the feeling of being a caregiver or their experiences, not focusing on their needs of being a caregiver. The studies included in this integrative review are shown in Chart 1.

Chart 1 - Sample of integrative review studies - Portugal, 2016.

\begin{tabular}{|c|c|c|c|c|}
\hline Title & Authors & Year & Methodology & Country \\
\hline $\begin{array}{l}\text { Assessment of patient and caregiver needs in fragile X-associ- } \\
\text { ated tremor/ataxia syndrome by utilizing Q-sort methodology }\end{array}$ & $\begin{array}{l}\text { Gane, Losif, Flynn-Wilson, Venturino, } \\
\text { Hagerman \& Seritanan } 7)\end{array}$ & 2010 & Qualitative & USA \\
\hline $\begin{array}{c}\text { Family caregivers' needs predict functional recovery of older } \\
\text { care recipients after hip fracture }\end{array}$ & Shyu, Chen, Wu \& Cheng(8) & 2010 & Quantitative & Thailand \\
\hline $\begin{array}{l}\text { Family needs and psychosocial functioning of caregivers for in- } \\
\text { dividuals with spinal cord injury from Colombia, South America }\end{array}$ & $\begin{array}{l}\text { Arango-Lasprilla, Plaza, Drew, } \\
\text { Perdomo, Pizarro \& Kreutzer(9) }\end{array}$ & 2010 & Quantitative & Colombia \\
\hline $\begin{array}{l}\text { Necesidades familiares y su relación con las características } \\
\text { psicosociales que presentan los cuidadores de personas con } \\
\text { demencia - Family needs and their relationship with psycho- } \\
\text { social functioning in caregivers of people with dementia }\end{array}$ & Moreno, Arango-Lasprilla \& Rogers ${ }^{(10)}$ & 2010 & Quantitative & Colombia \\
\hline $\begin{array}{l}\text { Can we move beyond burden and burnout to support the } \\
\text { health and wellness of family caregivers to persons with } \\
\text { dementia? Evidence from British Columbia, Canada }\end{array}$ & Lilly, Robinson, Holtzman \& Bottorff(3) & 2011 & Qualitative & Canada \\
\hline $\begin{array}{l}\text { Cuidador de pessoa com acidente vascular encefálico - ne- } \\
\text { cessidades, sentimentos e orientações recebidas }\end{array}$ & Oliveira, Garanhani \& Garanhani ${ }^{(1)}$ & 2011 & Qualitative & Brazil \\
\hline $\begin{array}{c}\text { Becoming a caregiver: new family carers' experience during } \\
\text { the transition from hospital to home }\end{array}$ & Plank, Mazzoni \& Cavada ${ }^{(11)}$ & 2012 & Qualitative & Italy \\
\hline $\begin{array}{l}\text { Stroke family caregivers' support needs change across the } \\
\text { care continuum: a qualitative study using the timing it right } \\
\text { framework }\end{array}$ & Cameron, Naglie, Silver \& Gignac ${ }^{(12)}$ & 2013 & Quantitative & Canada \\
\hline $\begin{array}{c}\text { Traumatic Brain Injury: Unmet Support Needs of Caregivers } \\
\text { and Families in Florida }\end{array}$ & $\begin{array}{l}\text { Dillahunt-Aspillaga, Jorgensen-Smith, } \\
\text { Ehlke, Sosinski, Monroe \& Thor }{ }^{(13)}\end{array}$ & 2013 & Qualitative & USA \\
\hline $\begin{array}{l}\text { Needs of family caregivers of stroke patients: a longitudinal } \\
\text { study of caregivers' perspectives }\end{array}$ & Tsai, Yip, Tai \& Lou ${ }^{(14)}$ & 2015 & Quantitative & Thailand \\
\hline $\begin{array}{c}\text { Experiences of burden, needs, rewards and resilience in fam- } \\
\text { ily caregivers of people living with Motor Neurone Disease/ } \\
\text { Amyotrophic Lateral Sclerosis: A secondary thematic analysis } \\
\text { of qualitative interviews }\end{array}$ & Weisser, Bristowe \& Jackson ${ }^{(15)}$ & 2015 & Qualitative & England \\
\hline
\end{tabular}


From analysis of the presented studies, five thematic areas emerged, as illustrated in Figure 3: transition into care, being responsible for everything, the importance of support, access to formal support, communication and information processes, which will be covered in more depth.

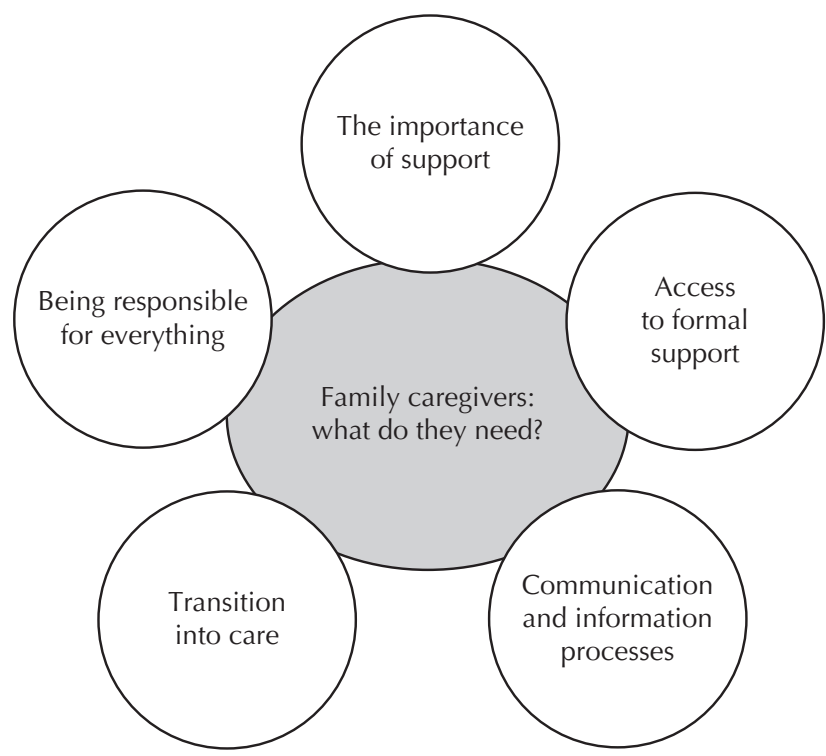

Figure 3-Thematic areas of the integrative review - Portugal, 2016.

\section{DISCUSSION}

\section{TRANSITION INTO CARE - THE NEED FOR KNOWLEDGE AND} LEARNING

Transition into the role of being a caregiver for a dependent person is a complex process that involves many variables. Transition is a concept associated to the crisis theory which occurs, as mentioned by Meleis in the theory of transitions, from transition processes arising from either developments, or health/disease ${ }^{(16)}$. The transition period is viewed as a period of great importance in learning skills for the amount of care required for the patient ${ }^{(11)}$. To (provide) care in an independent manner, caregivers need to acquire new knowledge and skills in the self-care dimension to meet all the activities of daily life, particularly regarding mobilization, transfer, medical care at home, exercises for rehabilitation, how to provide care at home, managing the unexpected, among others ${ }^{(12)}$. Confronting this new role takes place as soon as the dependent person and the caregiver return home, faced with new difficulties. Activities related to feeding, personal hygiene, mobility and dressing, previously performed with ease in daily life, have become tasks that require specific care and support ${ }^{(1)}$.

The domain of knowledge and learning how-to for family caregivers is one of the needs mentioned in most studies $^{(7,9,11-12,14-15)}$, as this allows for better understanding of this new role of Being the caregiver. Although the progressive nature of this process is visible in some studies, namely its variation in complexity and amplitude with regard to special needs $s^{(1,7,9,12,14-15)}$, the family caregiver adapts to the situation after a period and feels like they can overcome these needs ${ }^{(1)}$.

A longitudinal study of 60 family caregivers for patients of a stroke (cerebrovascular accident - CVA) observed a change in the needs of caregivers over time: before hospital discharge, two weeks after hospitalization and 3 months after hospitalization, revealing a decrease of these needs over time $^{(14)}$. The omnipresent fear of the unknown enhances the perceived lack of information and preparation, especially in the pre-discharge period, but reducing in the post-discharge period $^{(11)}$. The same results are presented in another longitudinal study of 10 family caregivers for patients with Motor neuron disease/ Amyotrophic Multiple Sclerosis, followed for 2 years. In this study, the authors stress that initially there were many needs; however, over time, they seemed to become less prevalent as the caregiver became more experienced, despite the person's condition deteriorating ${ }^{(15)}$.

In contrast, a longitudinal study with 18 caregivers of dependent patients on two occasions of before and after hospital discharge emphasizes that what changed over time was just the focus of the questions. Concerns of the caregivers slowly moved away from the recipient only in the post-discharge period, and they began to seek recognition of their own needs and appreciate the care provided ${ }^{(11)}$.

\section{Being Responsible fOR eVerything - Need for time FOR THE PLURALITY OF ACTIVITIES}

The feeling of being responsible for everything is a fundamental characteristic that caregivers experience, stringing together various needs. The need to try to handle a variety of tasks simultaneously weighs on caregivers, creating a bur$\operatorname{den}^{(11)}$. A multiplicity of previously existing roles is added to the caregiver role, which makes it difficult to take on this new role due to the difficulty inherent in time management, interaction and conflict of some of the roles. Conciliating the role of family caregivers with maintaining various roles and social relations becomes a challenge for caregivers, which can cause tension and conflict in this context $^{(13)}$. One study enumerates some of these needs: having time to sleep; help for cooking and shopping; having time for family and friends; being able to go to church; having time for themselves ${ }^{(14)}$.

This role is reported as forgotten and abandoned for an indefinite period by caregivers ${ }^{(3)}$. Family caregivers must ensure the tasks that the dependent person is unable to do for themself, such as personal hygiene and mobility. However, incorporating many other activities for the person under their care such as ensuring a suitable environment, providing constant supervision and emotional support, managing difficult behavior, making decisions on their behalf, financial management of care, as well as providing nursing care and therapeutic tasks. In addition to specific care and responsibilities for the dependent family member, caregivers must continue to perform daily tasks that were already their responsibility before: being a mother, wife, cooking, and trying to juggle a multitude of tasks simultaneously ${ }^{(11)}$.

In a study of 73 family caregivers of older adults with dementia, depression and caregiver burden were associated to some needs in this theme, such as helping around the house, having time to relax and time to sleep ${ }^{(10)}$. Thus, it is important to provide strategies in this process to help 
caregivers manage their conflicting roles and ensure the maintenance of caregivers' health ${ }^{(14)}$.

\section{THE IMPORTANCE OF SUPPORT - EMOTIONAL AND INTERPERSONAL NEEDS}

Support plays a decisive role in adapting to and in exercising the role of caregiver to obtain emotional support in a very vulnerable period ${ }^{(11)}$ for their own families ${ }^{(17)}$.

Emotional and interpersonal needs, namely being able to rely on someone to vent and to get recognition for their care efforts from friends and family are described throughout the analyzed studies, showing the importance of support for caregivers ${ }^{(1-3,7,71-15)}$.

Research results indicate that caregivers experience many challenges, including unmet needs in areas of relational support, such as maintaining long-term relationships and emotional support ${ }^{(7)}$. Developing strategies to support family caregivers and care recipients must be a focus of attention in the care for the family ${ }^{(18)}$.

Within emotional needs, some of them are listed as being: the need of having help to maintain hope for the future; being encouraged to ask others for help; expressing their feelings about the patient to someone who went through the same experience; having a partner or friends who understand how difficult this role is; having help/support with doubts and fears about the future; having time to go to their temple or church; discussing their feelings about the patient to be ensured that having strong negative feelings such as anxiety, worry, sadness, guilt and anger is normal ${ }^{(14)}$.

In a study of family caregivers of patients who suffered a stroke (cerebrovascular accident - CVA), emotions and feelings experienced in transition to the role of caregiver are stressed, as this is an unexpected and unfamiliar time initially generating an impact that culminates in an explosion of very intense feelings experienced by the caregiver ${ }^{(1)}$. Among them, feelings of hopelessness, fear and insecurity about the unknown and the future from that point forward are mentioned. The caregiver experiences an ambivalence of feelings demonstrated by happiness and hope, in contrast to feelings of stress, anxiety and deep sadness, which are expressed by continuous weeping/crying, demonstrating feelings of being close to losing control, accompanied by abdicating self-care to take care of others ${ }^{(1)}$.

As pointed out in one of the studies, when caregivers reflect on the necessary support in this context, family members are described as essential ${ }^{(11)}$. Family is referred to as a major source of psychological and organizational support, as well as a few close friends. Thus, they report feeling alone and abandoned when this informal support disappears completely, hoping that it would be offered without the need of asking for it.

Similarly, it was found that most caregivers reported high levels of overload, depression and health problems, and that regardless of the sociodemographic characteristics of caregivers, there is a relationship between some of the family's needs and the presence of these problems. Moreover, the need for emotional support and counseling are the best predictors of support for caregivers ${ }^{(10)}$.
ACCESS TO FORMAL SUPPORT - SOCIAL NEEDS, SUPPORT NETWORK FOR CAREGIVERS, FINANCIAL AND STRUCTURAL SUPPORT

Formal support is crucial for an effective transition into the role of caregiver, because from support it is possible to access health information, professional support and community network support ${ }^{(14)}$. Social needs, a support network for caregivers and economic and structural support are all described in the analyzed studies, with the importance of formal support being highlighted ${ }^{(1,3,7-15)}$. Caregivers reported different experiences associated with formal support; some felt supported and involved in nursing and therapeutic procedures, while others experienced little help, as well as a lack of understanding and empathy ${ }^{(11)}$. Some expressions of frustration from caregivers were directed toward their desire to receive more formal support regarding information and referral, home service/support for the patient, and relief services for themselves ${ }^{(3)}$. Temporary care needs or other help for the person are also mentioned; the need to participate in a support group; financial help with the costs; special equipment to meet the physical needs; nursing services at home; and help with transport.

In a study of 120 family caregivers of older women who had suffered a hip fracture, $42.6 \%$ of caregivers reported having at least one need for medical monitoring services, $13.5 \%$, at least one need for social services and $13.5 \%$, the need to join a support group and/or counseling to relieve stress. It is important to note that special attention should be given to caregivers who report having no needs regarding the provided care, a support group or help from social services ${ }^{(8)}$.

One of the most requested forms of support was rest for the caregiver, which was referred to as being very bureaucratic and difficult to get ${ }^{(3)}$. The lack of economic resources for purchasing materials for the new role, such as adapting facilities/buildings to provide residential care when architectural barriers are identified in the physical structure of the house can also be highlighted, making it difficult to provide proper care ${ }^{(1)}$. In general, personal interactions with groups of people and non-profit caregiver support were seen as some of the most beneficial sources of information and support ${ }^{(3)}$.

Many caregivers have limited access to information and little knowledge of existing support in their communities. Furthermore, even if these resources are available (for example for caregiver rest), usually the family caregiver feels an obligation to provide the care and does not end up using them ${ }^{(9)}$.

\section{COMMUNICATION AND INFORMATION PROCESSES - NeED FOR INFORMATION, COMMUNICATION}

The role of nurses is significant as qualified health professionals to transmit the information necessary for decision-making to care ${ }^{(19)}$. The need for information and communication with health professionals was a key issue for caregivers $^{(1,3,7-12,14)}$. They emphasized the importance of how the information should be transmitted in terms of quality and quantity ${ }^{(7)}$. The need for consistent, reliable and current information was reported by caregivers, highlighting the challenge that they experienced in gathering information ${ }^{(3)}$. 
With regard to guidance and information received by family caregivers, the results indicate that was not enough to make them feel secure in providing care, and perhaps may have even contributed to increased fears relating to the care ${ }^{(1)}$. Caregivers expressed their preference for a more structured approach, complemented by some written information so they could review the material at a later date ${ }^{(12)}$. Some caregivers also expressed that too much information was transmitted and provided all at once ${ }^{(11)}$.

Preparing the future caregiver before hospital discharge can increase satisfaction of their needs during and after discharge, and often contributes to developing their perception of balance between the new and old activities involved in their routines ${ }^{(1)}$. As a consequence, one of the priority needs of the caregiver is to receive information and training from health professionals to modify their decision making. However, only upon arriving home do caregivers become aware of the full sense of caring, realizing a realistic picture of the situation. Considering these issues, the possibility of caregivers experiencing this new role through short weekend periods prior to hospital discharge should be considered ${ }^{(11)}$.

On the other hand, according to caregivers' reports it can be observed that learning about care was not mentioned as part of the guidelines communicated by health professionals ${ }^{(1)}$. Perhaps because of the feeling of being neglected by health professionals, they seek informal sources of information, giving them greater credibility and trust ${ }^{(11)}$.

Communication between health care professionals and caregivers during hospitalization is crucial, especially when discussing the needs of care and providing information ${ }^{(14)}$, and especially for those who are new in this role having to start a new chapter in their lives. Communication is a process that allows for a relationship between the health team and caregivers, not only integrating a dimension of content, but also a dimension of interpersonal relationships ${ }^{(11)}$.

Thus, the importance of the relationship between family caregivers and health professionals is observed, particularly of nurses since they are the professionals who spend the most time next to the patient during hospitalization ${ }^{(1)}$. It is argued that promoting positive communication strategies is essential for developing an effective relationship between caregiver and health workers, and especially the nurses who must have an empathetic attitude to encourage caregivers to express their needs ${ }^{(11)}$.

Recognizing the needs of family caregivers is extremely important, considering that it is the first step in diagnosing subsequent planning of nursing interventions that can facilitate the transition process ${ }^{(19)}$. It is crucial to take advantage of this diagnosis, in order to introduce changes in the approach to caregivers, thereby facilitating their role in the family environment. Providing this attention to caregivers will promote personal and family health for dependents cared for at home ${ }^{(20)}$.

\section{CONCLUSION}

The transition into the caregiver role is complex and incorporates different needs throughout the process. The nurse has an important role and should meet the needs of family caregivers and the person they are caring for.

Five thematic areas were identified from the analyzed studies in this integrative review: transition into care, being responsible for everything, the importance of support, access to formal support, communication and information in decision making processes. There are many needs in various areas, such as the need for knowledge and learning for self-care arising from the transition to the new role of caregiver. These needs have a progressive character, in which know-how takes on greater importance at an early stage of the process.

Moreover, new tasks associated with care, which are unequally distributed among the family members, added to previously existing roles for caregivers cause imbalance in the family unit due to the time requirements necessary to perform the various activities that are expected from them.

The emotional needs are described as an important source of support for this new role, reducing caregiver burden. The importance of formal support, notably social needs, including rest for the caregiver, the existence of a support network for caregivers, and financial and structural support for care are also described. Finally, a mention of information and communication needs with health professionals, stressing the difficulty that the caregiver has in gathering information for their decision-making, thus seeking out informal information sources.

Considering the unique and unrepeatable character of this new role, we highlight that despite the scientific studies incorporated in this integrative review being developed in different sociopolitical contexts, including patients with different pathologies, and taking into account their uniqueness, the evidenced needs seem to be, in a sense, transversal.

Evidence arising from this integrative review has practical implications in the effective monitoring of caregivers in the community and the methodology used to empower caregivers to care, as well as alerting nurses to modify interventions according to the actual needs of caregivers.

\section{RESUMO}

Objetivo: Este estudo teve como objetivo identificar quais as principais necessidades manifestadas pelo cuidador familiar no cuidado à pessoa dependente. Método: Realizou-se uma revisão integrativa da literatura no período entre 2010 e 2015 com o recurso de instrumentos de busca específicos, nas bases de dados EBSCO e SCOPUS. Resultados: Foram selecionados 11 artigos A análise da evidência científica obtida permitiu organizar os resultados em cinco áreas temáticas: a transição para o cuidar, o ser responsável por tudo, a importância do suporte, o acesso aos apoios formais, a comunicação e a informação na tomada de decisão. Conclusão: Os resultados demonstram que o cuidador apresenta inúmeras necessidades em áreas distintas, as quais devem ser abordadas nas intervenções de enfermagem.

\section{DESCRITORES}

Cuidadores; Família; Assistência Domiciliar; Pessoas com Deficiência; Cuidados de Enfermagem; Revisão. 


\section{RESUMEN}

Objetivo: Este estudio tuvo como objetivo identificar cuáles son las principales necesidades manifiestas por el cuidador familiar en el cuidado a la persona dependiente. Método: Se llevó a cabo una revisión integrativa de la literatura en el período entre 2010 y 2015 con el recurso de instrumentos de búsqueda específicos, en las bases de datos EBSCO y SCOPUS. Resultados: Fueron seleccionados 11 artículos. El análisis de la evidencia científica permitió organizar los resultados en cinco áreas temáticas: la transición al cuidar, el ser responsable de todo, la importancia del soporte, el acceso a los apoyos formales, la comunicación y la información en la toma de decisión. Conclusión: Los resultados demuestran que el cuidador presenta innumerables necesidades en áreas distintas, las que se deben abordar en las intervenciones de enfermería.

\section{DESCRIPTORES}

Cuidadores; Familia; Atención Domiciliaria de Salud; Personas con Discapacidad; Atención de Enfermería; Revisión.

\section{REFERENCES}

1. Oliveira BC, Garanhani ML, Garanhani MR. Caregivers of people with stroke - needs, feelings and guidelines provided. Acta Paul Enferm [Internet]. 2011 [cited 2016 Feb 04];24(1):43-9. Available from: http://www.scielo.br/pdf/ape/v24n1/en_v24n1a06.pdf

2. Ângelo M. Antropologia para enfermagem. In: Nakamura E, Martin D, Santos JF, organizadoras. Cultura e cuidado da família. Barueri: Manole; 2009. p. 82-99.

3. Lilly M, Robinson C, Holtzman S, Bottorff J. Can we move beyond burden and burnout to support the health and wellness of family caregivers to persons with dementia? Evidence from British Columbia, Canada. Health Soc Care Community. 2012;20(1):103-12.

4. Figueiredo D. Cuidados familiares ao idoso dependente. Lisboa: CLIMEPSI; 2007. (Cadernos Climepsi de Saúde, 4).

5. Mendes KDS, Silveira RCCP, Galvão CM. Revisão integrativa: método de pesquisa para a incorporação de evidências na saúde e na enfermagem. Texto Contexto Enferm. 2008;17(4):758-64.

6. Whittemore R, Knafl K. The integrative review: updated methodology. J Adv Nurs. 2005;52(5):546-53.

7. Gane L, losif A, Flynn-Wilson L, Venturino M, Hagerman R, Seritan A. Assessment of patient and caregiver needs in fragile X-associated tremor/ataxia syndrome by utilizing Q-sort methodology. Aging Ment Health. 2010;14(8):1000-7.

8. Shyu Y, Chen M, Wu C, Cheng H. Family caregivers' needs predict functional recovery of older care recipients after hip fracture. J Adv Nurs. 2010;66(11):2450-9.

9. Arango-Lasprilla JC, Plaza SL, Drew A, Romero JL, Pizarro JA, Francis K, et al. Family needs and psychosocial functioning of caregivers of individuals with spinal cord injury from Colombia, South America. NeuroRehabilitation. 2010;27(1):83-93.

10. Moreno J, Arango-Lasprilla JC, Rogers H. Necesidades familiares y su relación con las características psicosociales que presentan los cuidadores de personas con demencia. Psicol Caribe [Internet]. 2010 [citado 2016 Feb. 04];(26):1-35. Disponible en: http://rcientificas. uninorte.edu.co/index.php/psicologia/article/viewFile/1069/3148

11. Plank A, Mazzoni V, Cavada L. Becoming a caregiver: new family carers' experience during the transition from hospital to home. J Clin Nurs. 2012;21(13-14):2072-82.

12. Cameron J, Naglie G, Silver F, Gignac M. Stroke family caregivers' support needs change across the care continuum: a qualitative study using the timing it right framework. Disabil Rehabil. 2013;35(4):315-24.

13. Dillahunt-Aspillaga C, Jorgensen-Smith T, Ehlke S, Sosinski M, Monroe D, Thor J. Traumatic brain injury: unmet support needs of caregivers and families in Florida. PLoS One 2013;8(12):e82896.

14. Tsai PC, Yip PK, Tai JJ, Lou ME. Needs of family caregivers of stroke patients: a longitudinal study of caregivers' perspectives. Patient Prefer Adherence. 2015;9:449-57.

15. Weisser FB, Bristowe K, Jackson D. Experiences of burden, needs, rewards and resilience in family caregivers of people living with Motor Neurone Disease/Amyotrophic Lateral Sclerosis: a secondary thematic analysis of qualitative interviews. Palliat Med. 2015;29(8):737-45.

16. Meleis AH. Transitions theory: middle range and situation specific theories in nursing research and practice. New York: Springer; 2010.

17. Li CY, Murray M. A review of conceptualisation of expressed emotion in caregivers of older adults with dementia. J Clin Nurs. 2015;24(34):332-43.

18. Park EO, Schumacher KL. The state of the science of family caregiver-care receiver mutuality: a systematic review. Nurs Inq. 2014;21(2):140-52.

19. Melo RMC, Rua MS, Santos CSVB. Necessidades do cuidador familiar no cuidado à pessoa dependente: uma revisão integrativa da literatura. Rev Ref. 2014;IV(2):143-51.

20. Ferré-Grau C, Casado MS, Cid-Buera D, LLeixà-Fortuño M, Monteso-Curto P, Berenguer-Poblet M. Caring for family caregivers: an analysis of a family-centered intervention. Rev Esc Enferm USP [Internet]. 2014 [cited 2016 Feb 04];48(n.spe):87-94. Available from: http://www. scielo.br/pdf/reeusp/v48nspe/0080-6234-reeusp-48-esp-089.pdf 